\begin{tabular}{lc}
\hline CURRENT & ISSN: 0973-4929, Vol. 13, №. (2) 2018, Pg. 187-193 \\
WORLD & Current World Environment
\end{tabular}

ENYIRONMENT

Journal Website: www.cwejournal.org

\title{
Environmental Implications of pH in a Pervious Concrete Pavement on Highway BR-319, Amazonas, Brazil
}

\author{
EVAILTON ARANTES DE OLIVEIRA ${ }^{1 *}$, MURILO FERREIRA DOS SANTOS ${ }^{2}$, \\ JÉSSICA ADRIANE AFONSO SOUZA ${ }^{2}$, ARLENE M. LAMÊGO DA S. CAMPOS ${ }^{3}$, \\ MARIA DO P. S. LAMÊGO OLIVEIRA', MARIA JOÃO CORREIA DE \\ SIMAS GUERREIRO ${ }^{4}$ and MARIA ALZIRA PIMENTA DINIS ${ }^{4}$
}

\author{
${ }^{1}$ University Fernando Pessoa (UFP), 4249-004 Porto, Portugal. \\ 2Uninorte Laureat University International, 69.020-031 Manaus, Brazil. \\ ${ }^{3}$ Department of Civil Engineering, Federal Institute of Education, Science and Technology \\ of Amazonas - IFAM, 69.020-120 Manaus, Brazil. \\ ${ }^{4}$ UFP Energy, Environment and Health Research Unit (FP-ENAS), University Fernando \\ Pessoa (UFP), Praça 9 de Abril 349, 4249-004 Porto, Portugal.
}

\begin{abstract}
This research studies the carbonation phenomenon of cement due to the reaction of its components with water. In this chemical reaction occurs the formation of calcium carbonate and the absorption of $\mathrm{CO}_{2}$ in the atmosphere, which contributes to the reduction of the Greenhouse Effect. However, carbonation also causes pathologies such as efflorescence, staining and corrosion of steel in concrete. This research shows the results of experiments with specimens of concrete permeable, made with cement and big aggregates (calcareous stone) in the ratio of 1: 4.4 (cement: stone) and a factor of 0.3 for water / cement. The specimens were kept in contact with water containing different amounts of $\mathrm{CO}_{2}$ - distilled, ionized alkaline, carbonated, and tap water. After the experiments were carried out, an increase in $\mathrm{pH}$, a mean compressive strength of $12.3 \mathrm{MPa}$ and a permeability rate of $1.28 \mathrm{I} / \mathrm{h}$ was observed. The results show that the permeable concrete did not present any pathologies resulting from the carbonation during the period of the research, which recommended the same for use in road pavements.
\end{abstract}

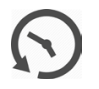

Article History

Received: 25 May 2018 Accepted: 23 August 2018

\section{Keywords}

Brazil,

Carbonation, Highway pavement,

Pervious concrete,

Resistance to

Compression. 


\section{Introduction}

Concrete has cement as a binder, therefore, it is subject to two phenomena: calcination and carbonation ${ }^{1}$. The cement manufacturing process consumes energy and generates carbon dioxide $\left(\mathrm{CO}_{2}\right)$ due to calcination, whereas carbonation of cement, a natural process of calcium carbonate formation in the concrete hydration process, uptakes $\mathrm{CO}_{2}$ from the environment, an interesting environmental factor that may contribute to reduction of this greenhouse gas ${ }^{2,3}$. In fact, cement carbonation in construction may reduce $\mathrm{CO}_{2}$ in the environment, with a positive impact on the greenhouse effect. Nonetheless, carbonation may contribute to concrete pathology by steel corrosion in reinforced concrete 4 . The importance of investigating the environmental implications of $\mathrm{pH}$ variation in drainage water from porous concrete is related to cement carbonation ${ }^{5}$. Upon the hydrolysis reaction, an increase in the solubility of calcium carbonate, incorporates carbon dioxide, leading to an acidity in the water, once the system is in equilibrium. Sustainability requirements in today's constructions compel to investigate materials whose waste can be recycled ${ }^{3}$. This research work focused on the effects of carbonation in porous concrete, which may include recycling of concrete by using it as an aggregate contributing to pavements 6 construction sustainability. The main objective of this study was to investigate evidence of carbonation in specimens of pervious concrete, under laboratory and field conditions of pressure and temperature, and to verify the integrity of specimens of pervious concrete subject to different types of water: distilled, alkaline ionized water, carbonated water and tap water.

\section{Materials and Methods}

This study was developed in Manaus, in the Amazon region in Brazil, and involved laboratory and field experiments.

\section{Pervious Concrete Specimens}

Pervious concrete specimens were formed based on the Brazilian standard NBR 57387, that defines the procedures to mold and cure concrete specimens. Based on studies of traits, preparation methods, standard quality control as well as permeability concrete optimization methods ${ }^{8}$, ten cylindrical specimens of pervious concrete were formed, with a cement to coarse aggregate $1: 4.4$ ratio and a water/ cement factor of 0.3 to compression (Table 1 ).

Table 1: Pervious concrete specimens characteristics

\begin{tabular}{ll}
\hline Material & Ratio \\
\hline cement : coarse aggregate ratio & $1: 4.4$ \\
water / cement factor & 0.3 \\
aggregate $(4.8$ a $9.5 \mathrm{~mm})\left(\mathrm{kg} / \mathrm{m}^{3}\right)$ & 1660 \\
cement $\left(\mathrm{kg} / \mathrm{m}^{3}\right)$ & 374 \\
\hline
\end{tabular}

The specimens were molded into cylindrical shapes of $10 \mathrm{~cm}$ in diameter by $20 \mathrm{~cm}$. The compaction consisted on applying 15 strokes with a shank, by layer of equal thickness. Vibration, curing and demolding were performed according to the guidelines of Brazilian standard NBR 5738, considering that the characteristics of pervious concrete differ from common concrete ${ }^{9}$.

The infiltration rate was evaluated using distilled (DIS), ionized (ION), tap (TAP) and carbonated (CAR) water (Figure 1). Water adsorption was calculated by weight difference after the samples were left to air dry for 24 hours and after water (DIS, ION, TAP, and CAR) had infiltrated through the specimen.

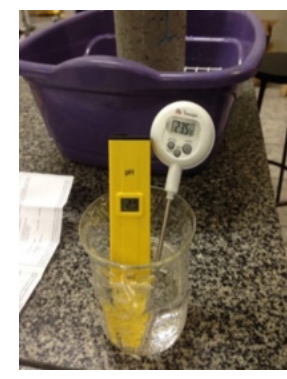

a)

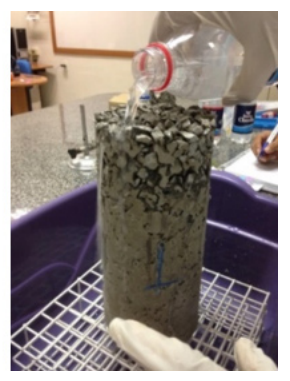

b)
Fig. 1: measurement of a) pH and temperature; b) infiltration rate

The $\mathrm{pH}$ variation during carbonation and calcination 10

The chemical reaction in cement manufacture, where calcium carbonate dissociates into carbon dioxide and calcium oxide, requires a lot of thermal energy 
and releases its carbon dioxide into the atmosphere. Carbonation (equations 1 and 2) is the inverse reaction of calcination (Equation 3), where carbon dioxide is slowly absorbed by the concrete during its lifetime (Equations 1 to 3).

$\mathrm{CaCO}_{3}(\mathrm{~s}) \leftrightarrow \mathrm{CO}_{3}^{2-}(\mathrm{aq})+\mathrm{Ca}^{2+}(\mathrm{aq}) \quad$ (Equation 1)

$\mathrm{CO}_{3}{ }^{2-}(\mathrm{aq})+\mathrm{H}_{2} \mathrm{O} \leftrightarrow \mathrm{HCO}^{3-}(\mathrm{aq})+\mathrm{OH}(\mathrm{aq}) \quad$ (Equation 2)

The hydrolysis reaction consumes $\mathrm{CO}_{3}{ }^{2-}(\mathrm{aq})$ and increases the solubility of calcium carbonate. Therefore, the incorporation of carbon dioxide creates an acidity in water, which can be detected by $\mathrm{pH}$ measurement, after the equilibrium displayed in Equation 3:
$\mathrm{CaCO}_{3}(\mathrm{~s})+\mathrm{CO}_{2}(\mathrm{~g})+\mathrm{H}_{2} \mathrm{O} \leftrightarrow 2 \mathrm{HCO}^{3}(\mathrm{aq})+\mathrm{Ca}^{2+}(\mathrm{aq})$

(Equation 3)

Thus, the indication of $\mathrm{pH}$ change can be used as a method to verify if carbonation in the specimens of pervious concrete is occuring ${ }^{13}$. Evaluation of $\mathrm{pH}$ difference was performed in each sample (Figure 1), with a time interval of 24 hours, in the following order: DIS, ION, TAP, CAR. The samples were left to air dry for 24 hours, after which weighing with a precision scale of $\pm 0.2 \mathrm{~g}$ would take place.

\section{Results}

Pervious concrete specimen average infiltration rate, $\mathrm{pH}$ e temperature before/after percolation are presented in Table 2.

Table 2: Experimental data

\begin{tabular}{|c|c|c|c|c|c|c|c|c|c|c|}
\hline \multirow{2}{*}{\multicolumn{2}{|c|}{ Sample (g) }} & \multicolumn{5}{|c|}{$\begin{array}{l}\text { Infiltration } \mathrm{pH} \text { before/after } \\
\text { rate percolation }\end{array}$} & \multicolumn{4}{|c|}{$\begin{array}{l}\text { temperature before/after } \\
\text { percolation }\left({ }^{\circ} \mathrm{C}\right)\end{array}$} \\
\hline & & $(\mathrm{mm} / \mathrm{h})$ & DIS & ION & TAP & CAR & DIS & ION & TAP & CAR \\
\hline 1 & $3,354.30$ & 1.14 & $\begin{array}{l}7.4 / \\
7.1\end{array}$ & $\begin{array}{l}9.6 / \\
8.7\end{array}$ & $\begin{array}{l}8.5 / \\
5.1\end{array}$ & $\begin{array}{l}5.4 / \\
3.2\end{array}$ & $\begin{array}{l}22.7 / \\
21.9\end{array}$ & $\begin{array}{l}23.5 / \\
21.9\end{array}$ & $\begin{array}{l}27.0 / \\
24.2\end{array}$ & $\begin{array}{l}24.3 / \\
21.8\end{array}$ \\
\hline 2 & $3,236.90$ & 1.27 & $\begin{array}{l}8.2 / \\
7.1\end{array}$ & $\begin{array}{l}9.8 / \\
8.7\end{array}$ & $\begin{array}{l}8.6 / \\
5.1\end{array}$ & $\begin{array}{l}5.1 / \\
3.2\end{array}$ & $\begin{array}{l}22.9 / \\
22.1\end{array}$ & $\begin{array}{l}23.2 / \\
21.5\end{array}$ & $\begin{array}{l}25.9 / \\
22.8\end{array}$ & $\begin{array}{l}24.3 / \\
21.3\end{array}$ \\
\hline 3 & $3,308.20$ & 1.31 & $\begin{array}{l}7.6 / \\
7.1\end{array}$ & $\begin{array}{l}9.6 / \\
8.7\end{array}$ & $\begin{array}{l}7.8 / \\
5.1\end{array}$ & $\begin{array}{l}4.6 / \\
3.2\end{array}$ & $\begin{array}{l}22.5 / \\
21.3\end{array}$ & $\begin{array}{l}22.9 / \\
21.2\end{array}$ & $\begin{array}{l}27.1 / \\
23.4\end{array}$ & $\begin{array}{l}23.5 / \\
21.1\end{array}$ \\
\hline 4 & $3,304.80$ & 1.23 & $\begin{array}{l}7.6 / \\
7.1\end{array}$ & $\begin{array}{l}9.6 / \\
8.7\end{array}$ & $\begin{array}{l}8.5 / \\
5.1\end{array}$ & $\begin{array}{l}4.7 / \\
3.2\end{array}$ & $\begin{array}{l}22.5 / \\
21.6\end{array}$ & $\begin{array}{l}22.4 / \\
20.9\end{array}$ & $\begin{array}{l}27.0 / \\
22.9\end{array}$ & $\begin{array}{l}23.1 / \\
21.1\end{array}$ \\
\hline 5 & $3,285.80$ & 1.27 & $\begin{array}{l}7.5 / \\
7.1\end{array}$ & $\begin{array}{l}9.5 / \\
8.7\end{array}$ & $\begin{array}{l}8.3 / \\
5.1\end{array}$ & $\begin{array}{l}4.6 / \\
3.2\end{array}$ & $\begin{array}{l}22.3 / \\
21.1\end{array}$ & $\begin{array}{l}22.3 / \\
21.1\end{array}$ & $\begin{array}{l}25.3 / \\
22.3\end{array}$ & $\begin{array}{l}22.7 / \\
20.7\end{array}$ \\
\hline 6 & $3,148.50$ & 1.22 & $\begin{array}{l}8.0 / \\
7.1\end{array}$ & $\begin{array}{l}9.6 / \\
8.7\end{array}$ & $\begin{array}{l}8.8 / \\
5.1\end{array}$ & $\begin{array}{l}4.6 / \\
3.2\end{array}$ & $\begin{array}{l}22.2 / \\
21.8\end{array}$ & $\begin{array}{l}22.6 / \\
21.5\end{array}$ & $\begin{array}{l}25.3 / \\
22.3\end{array}$ & $\begin{array}{l}22.7 / \\
20.6\end{array}$ \\
\hline 7 & $3,257.00$ & 1.55 & $\begin{array}{l}7.7 / \\
7.1\end{array}$ & $\begin{array}{l}9.4 / \\
8.7\end{array}$ & $\begin{array}{l}8.3 / \\
5.1\end{array}$ & $\begin{array}{l}4.5 / \\
3.2\end{array}$ & $\begin{array}{l}21.8 / \\
20.6\end{array}$ & $\begin{array}{l}22.6 / \\
22.3\end{array}$ & $\begin{array}{l}26.1 / \\
23.4\end{array}$ & $\begin{array}{l}22.5 / \\
21.4\end{array}$ \\
\hline 8 & $3,405.90$ & 1.26 & $\begin{array}{l}7.4 / \\
7.1\end{array}$ & $\begin{array}{l}9.3 / \\
8.7\end{array}$ & $\begin{array}{l}8.2 / \\
5.1\end{array}$ & $\begin{array}{l}4.0 / \\
3.2\end{array}$ & $\begin{array}{l}21.3 / \\
20.6\end{array}$ & $\begin{array}{l}22.7 / \\
22.7\end{array}$ & $\begin{array}{l}25.8 / \\
23.6\end{array}$ & $\begin{array}{l}22.6 / \\
22.0\end{array}$ \\
\hline 9 & $3,164.30$ & 1.31 & $\begin{array}{l}8.2 / \\
7.1\end{array}$ & $\begin{array}{l}9.2 / \\
8.7\end{array}$ & $\begin{array}{l}9.0 / \\
5.1\end{array}$ & $\begin{array}{l}4.3 / \\
3.2\end{array}$ & $\begin{array}{l}21.5 / \\
21.2\end{array}$ & $\begin{array}{l}21.1 / \\
20.0\end{array}$ & $\begin{array}{l}25.3 / \\
23.9\end{array}$ & $\begin{array}{l}22.4 / \\
22.0\end{array}$ \\
\hline 10 & $3,269.90$ & 1.26 & $\begin{array}{l}8.8 / \\
7.1\end{array}$ & $\begin{array}{l}9.4 / \\
8.7\end{array}$ & $\begin{array}{l}8.5 / \\
5.1\end{array}$ & $\begin{array}{l}4.3 / \\
3.2\end{array}$ & $\begin{array}{l}21.6 / \\
21.5\end{array}$ & $\begin{array}{l}21.1 / \\
19.9\end{array}$ & $\begin{array}{l}25.0 / \\
24.3\end{array}$ & $\begin{array}{l}22.8 / \\
21.7\end{array}$ \\
\hline
\end{tabular}

\section{Discussion}

\section{Infiltration Rate}

As shown in Figure 3, the infiltration rate showed little variation between specimens for the same water type. The highest rates (smaller filtration time) were always under distilled water, suggesting that minerals may affect infiltration rates. Infiltration rate is within the expected parameters ${ }^{15}$. 


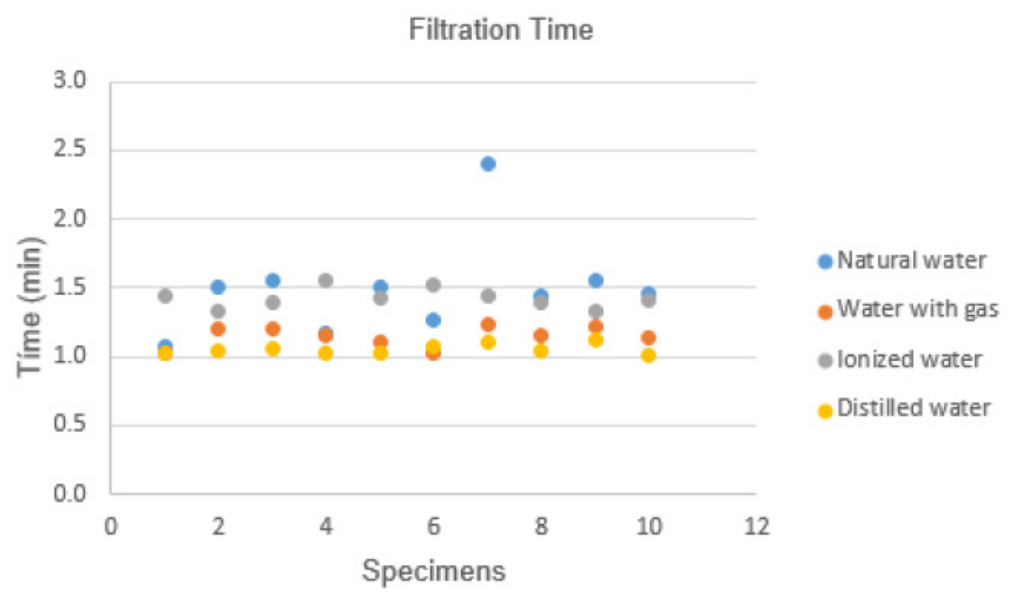

Fig. 2: Time of filtration of the different types of water in the specimens of pervious concrete

Nonetheless, the Kruskal-Wallis ANOVA test, using filtration time of tap water as a grouping variable, demonstrates that samples are homogeneous, with a $p$-value $=0.429$ for CAR, $p$-value of 1.000 for ION, and $p$-value of 0.317 for DIS. Table 3 shows the descriptive statistics of filtration times for the four water types.

Table 3: Filtration time descriptive statistics

\begin{tabular}{lllll}
\hline & \multicolumn{3}{l}{ Water type } & \\
\cline { 2 - 5 } & Tap & Carbonated & lonized & Distilled \\
\hline mean & 1.5 & 1.1 & 1.4 & 1.1 \\
standard deviation & 0.361 & 0.079 & 0.070 & 0.038 \\
variance & 0.130 & 0.006 & 0.005 & 0.001 \\
\hline
\end{tabular}

\section{Water adsorption}

Water adsorption in the specimens varied from $1.2 \%$ to $1.6 \%$, with distilled and tap water showing less adsorption than carbonated or ionized water (Table 3), based on the non-parametric Kruskal-
Wallis test with seven degrees of freedom, using weight difference of water as a grouping variable. Results showed a $p$-value $=0.339$ for CAR, $p$-value $=$ 0.357 for ION, and $p$-value $=0.339$ for DIS, implying that samples were homogeneous.

Table 4: Adsorption on pervious concrete specimens

\begin{tabular}{lc}
\hline Types of water & $\begin{array}{c}\text { Adsorption (\%) pervious } \\
\text { concrete specimens }\end{array}$ \\
\hline Distilled water (DIS) & 1.2 \\
lonized water (ION) & 1.6 \\
Tap water (TAP) & 1.2 \\
Carbonated water (CAR) & 1.5 \\
\hline
\end{tabular}


Figure 2 shows difference in weight before and after the infiltration process, suggesting that water adsorption is higher under ionized water, followed by carbonated water, distilled and tap water, suggesting that water with higher carbon concentration tends to adsorb more to concrete. Differences between samples are attributed to differences in porosity due to concrete molding.

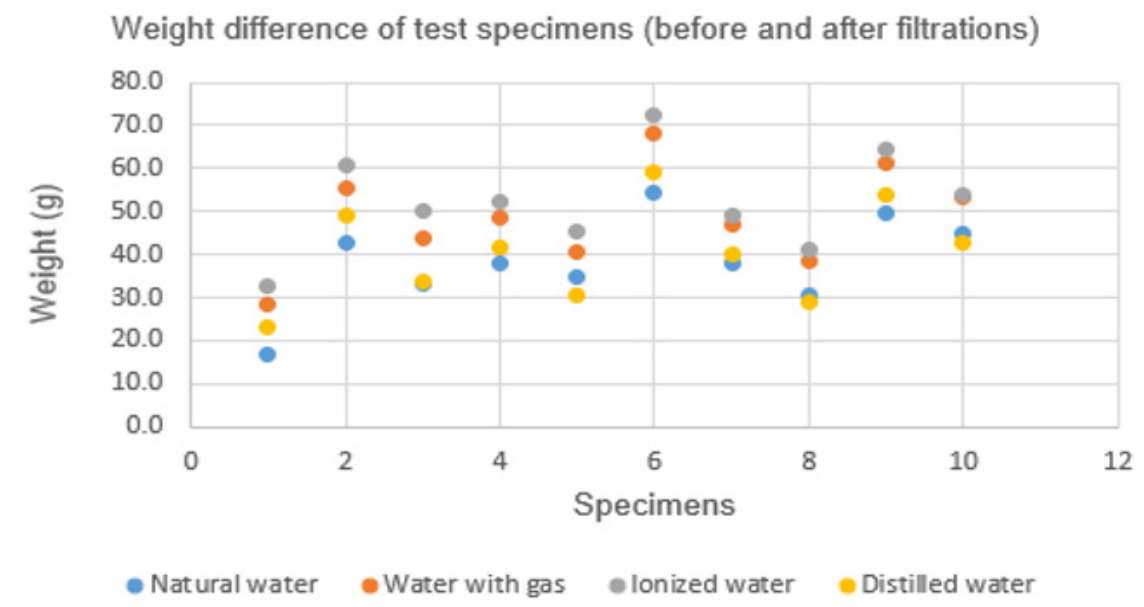

Fig. 3: Weight difference pervious concrete specimens, before and after water infiltration

As shown in Figure 4, all water samples filtered through the pervious concrete specimens changed their $\mathrm{pH}$. Tap water and carbonated water showed higher $\mathrm{pH}$ differences, whereas ionized and distilled water showed smaller differences. These results suggest that pervious concrete adsorbs $\mathrm{CO}_{2}$ from carbonated water, changing its $\mathrm{pH}$.

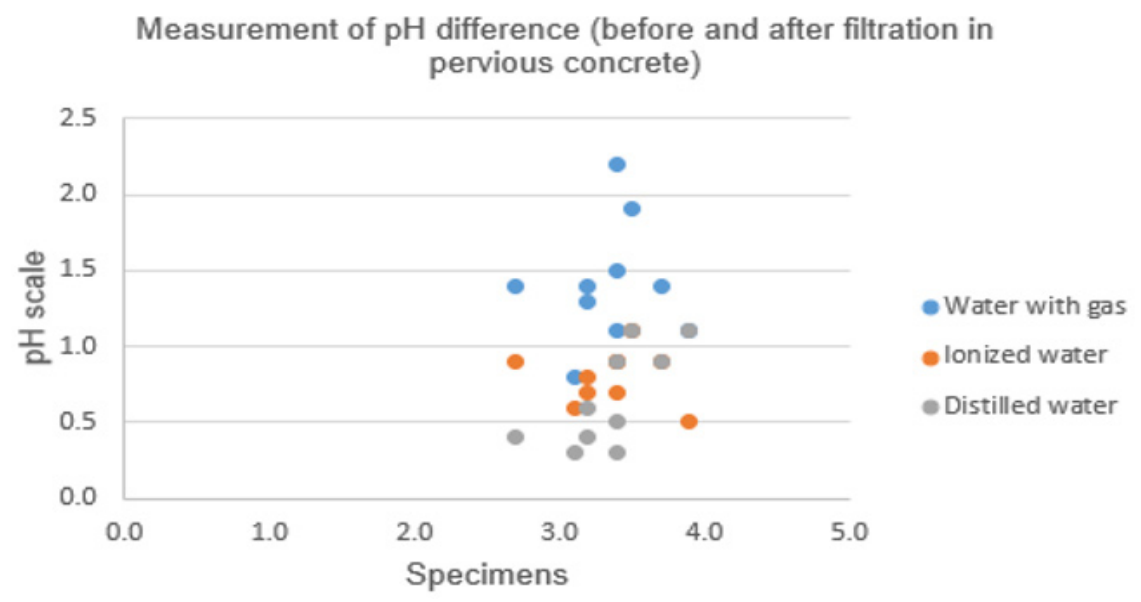

Fig. 4: pH difference of the pervious concrete specimens, before and after filtration of the different types of water

The Kruskal-Wallis test, using the difference data of $\mathrm{pH}$ of tap water as a grouping variable, resulted in a $p$-value of 0.860 for CAR, $p$-value of 0.471 for ION, and $p$-value of 0.481 for DIS, implying that samples are homogeneous $(p>0.05)$. 
Descriptive statistics (Table 5), the natural water presented the mean with the greatest difference of values between $\mathrm{pH}$ before and $\mathrm{pH}$ after filtration, while ionized water and distilled water showed the lowest mean with the difference between $\mathrm{pH}$ before and after $\mathrm{pH}$ filtration. It is assumed that natural water needs less filtration time to undergo greater $\mathrm{pH}$ changes, i.e., water with gas, ionized water and distilled water need to remain contained in the pores of the pervious concrete to undergo greater $\mathrm{pH}$ changes.

Table: 5 pH descriptive statistics

\begin{tabular}{lllll}
\hline & \multicolumn{2}{l}{ Water type } & \\
\cline { 2 - 5 } & Tap & Carbonated & Ionized & Distilled \\
\hline mean & 3.4 & 1.4 & 0.8 & 0.7 \\
standard deviation & 0.331 & 0.401 & 0.176 & 0.321 \\
variance & 0.109 & 0.161 & 0.031 & 0.103 \\
\hline
\end{tabular}

Having pervious concrete large and interconnected pores in addition to the typical micropores of cement paste $^{11}$, this structure allows ambient air and water to more easily reach the inner spaces. When water flows through pervious concrete, $\mathrm{pH}$ of water changes due to the calcium hydroxide and calcium carbonate in the cement slurry ${ }^{12}$, with lower $\mathrm{pH}$ values, indicating more calcium carbonate or a greater amount of carbonation. The $\mathrm{pH}$ change indicates that water encountered calcium hydroxide, with a $\mathrm{pH}$ increase. Nonetheless, in this experiment there was no time for formation of calcium carbonate, therefore, it was not possible to detect the carbonation by the reduction of $\mathrm{pH}$ in the samples, in these laboratory experiments.

\section{Conclusions}

The results obtained in the laboratory and in the field showed that:

- $\quad$ low absorption of tap and distilled water by pervious concrete specimens, is an advantage if it is intended to be used as road paving material, increasing stability under rainfall conditions;

- filtration time, associated to infiltration rate, showed little variation under different water types, suggesting that pervious concrete is use is not constrained by carbon concentration in water;

$\mathrm{pH}$ increase in water samples after infiltration through pervious concrete specimens, in the laboratory and in the field experiments suggest contact of rainwater with the calcium hydroxide in the cement paste, but carbonation and $\mathrm{CO}_{2}$ sequestration could not be detected probably because there was not enough time for calcium carbonate formation.

These preliminary studies suggest that carbonation was not detected by the methodology used, so it would be interesting to perform other tests, such as $X$-ray diffraction to identify the chemical components in the samples being tested that serve as evidence of carbonation in the cement.

\section{Acknowledgements}

The authors are grateful to University Fernando Pessoa (Porto - Portugal) for the guidance provided, Uninorte University - Laureat International for permission to use the Chemistry Laboratory and Concrete Laboratory of the Coordination of the Civil Engineering Course, Manaus, Amazon, Brazil, and the National Department of Infrastructure and Transport - DNIT, Brazil, for the support of the scientific research taking place. This research had no external funding sources. 


\section{References}

1. Haselbach I, Thomle J. An Alternative Mechanism for Accelerated Carbon Sequestration in Concrete. Sustainable Cities and Society. 2014;12:25.

2. Thomle J, Haselbach L. The Declining $\mathrm{pH}$ of Waters Exfiltrated Through Pervious Concrete. Sustainable Cities and Society. 2011;12:25.

3. Pade C, Guimarães M. The $\mathrm{CO}_{2}$ Uptake of Concrete in 100 Years Perspective. Cement and Concrete Research, 2007;37:1348-1356. Hõltz F. C. Use of Permeable Concrete in Urban Drainage: Technical Feasibility and Environmental Impact Analysis. Master's Dissertation UFRS, School of Engineering, Porto Alegre, Brazil, 2011.

4. Ho LS, Nakarai K, Ogwa Y, Sasaki T, Morioka M. Effect of Internal Water Content on Carbonation Progress in Cementtreated Sand and Effect of Carbonation on Compressive Strength. Cement and Concrete Composites. 2018; 85:9.

5. Branch JL, Epps R, Kosson DS. The Impact of Carbonation on Bulk and ITZ Porosity in Microconcrete Materials with Fly ash Replacement. Advances in Materials Science \& Engineering. 2018; 103:170.

6. El-Hassan H, Kianmehr P. Sustainability Assessment and Physical Characterization of Pervious Concrete Pavement made with GGBS. MATEC Web of Conferences, 2017;
120:07001.

7. Associação Brasileira de Normas Técnicas. NBR 5738: Molding and Cure of Cylindrical and Prismatic Concrete Samples. (In Portuguese), Rio de Janeiro, 1994.

8. Rangelov M, Nassiri S, Chen Z, Russell M, Uhlmeyer J. Quality Evaluation Tests for Pervious Concrete Pavements Placement. International Journal of Pavement Research and Technology. 2017;10(3):245.

9. Batezini R, Balbo JT. Study on the Hydraulic Conductivity by Constant and Falling head Methods for Pervious Concrete. IBRACON Structure and Materials Journal. 2015; 8(3),:248-259.

10. Arrigoni A, Pelosato R, Melià P, Ruggieri G, Sabbadini S, Dotelli G. Life Cycle Assessment of Natural Building Materials: The Role of Carbonation, Mixture Components and Transport in the Environmental Impacts of Hempcrete blocks. Journal of Cleaner Production. 2017;149:1051.

11. Georget F, Prévost JH, Huet B. Impact of the Microstructure Model on Coupled Simulation of Drying and Accelerated Carbonation. Cement and Concrete Research. 2018;104:1.

12. Hunnicutt W, Struble L, Mondal P. Effect of Synthesis Procedure on Carbonation of Calcium-silicate-hydrate. Journal of the American Ceramic Society. 2017;100: 3736. 